\title{
Seneca's De Clementia. An Overlooked Chapter in the Genealogies of Representation and Sovereignty
}

\author{
GONZALO BUSTAMANTE KUSCHEL \\ Universidad Adolfo Ibáñez, Santiago, Chile
}

\begin{abstract}
Summary
In the article, Seneca's figure is rehabilitated as relevant to understanding the emergence of sovereignty and modern representation. The idea put forth by the author of De Clementia would become one of the bases for Bodin's writings and is also present in Hobbes' work. During the Renaissance, De Clementia promoted monarchical forms.

In De Clementia, this Stoic philosopher presents Nero in a depersonalised form. He is not only the sovereign capable of shaping a multitude, representing it in its whole and giving it the character of "people", but also one who secures peace and rules with justice. Thus, in Seneca, one can discern a prototheory of sovereignty and representation, with decisionism as its result.

If these readings of Seneca are plausible, genealogies of modern concepts that interpret their emergence as a revolutionary Trennung (e.g. Schmitt and early Conceptual History) (Lehmann and Van Horn Melton, 1994; Lehmann and Richter, 1996) could be facing a problem of omission. The conceptual support for the process through which the medieval social and political world was destroyed and substituted by modernity does not come from Cicero's republican tradition, but from a monarchical notion of unity among the governor and the governed; an idea defended by Seneca, according to which absolute sovereignty would guarantee private property, contracts, and a sui iuris apolitical soul.
\end{abstract}

Keywords: Seneca, Begriffsgeschichte, Representation, Democracy, Sovereignty

\section{Framework}

Different instances of criticism to Hobbesian political representation have emerged from Pitkin's typical classification of Hobbes as a historical referent for that con- 
cept. ${ }^{1}$ Pitkin herself says that its characteristics are not enough to consider it as compatible with democratic representation. More recently, Tuck (2006) and Runciman (2010) have attempted to put forth the idea of a democracy-friendly Hobbes. On the other hand, Baumgold (1988: 45) describes the reason behind the importance of Hobbes' concept of representation in his political theory as follows:

It is Hobbes's contentious claim, contra the parliamentarians, that representation is a necessary feature of sovereign authority. The title 'representative' is simply, in other words, a synonym for 'sovereign'.

Before the emergence of this discussion in the English-speaking world, Hobbes' figure and his ideas of representation and authorisation were analysed in the midst of the German-speaking culture as a way to think about political and constitutional issues (such is the case of Schmitt during the Weimar Republic), to criticise modern bourgeois politics and society (Schelsky, 1981), and to criticise the emergence of modern political concepts (in which the original Begriffsgeschichte, influenced by Schmitt, would play a relevant role). Conceptual historians closer to Schmitt's genealogy who criticise modernity (e.g. Conze and Brunner in the past; Duso, Chignola, and Galli in the present) support an interpretation of the Hobbesian concept of representation aligning with that of Baumgold but including Schmitt's intention of criticising liberalism and representative democracy. Through his revolutionary elaboration of a merger between representation and authorisation by an absolute sovereign, Hobbes may have started a conceptual revolution that buried classical categories. My hypothesis is that such view of Hobbes as someone who revolutionised the notion of representation entails a genealogical error, that is, a mistaken consideration of the origin of such form of representation, which is prior to Hobbes (at least, in an earlier form) and in which Seneca plays a central role. I will state that, taking into account Seneca's influence on Bodin and Lipsius, and, in turn, their influence on Hobbes, Kantorowicz is correct to see the source of such "a conceptual revolution" in Seneca and his reinterpretation during the Middle Ages. In consequence, genealogically speaking, Hobbes is not a "revolutionary ground zero" starting point; he reflects a prior tradition.

1 She classifies Hobbes' concept of representation as a process through which, in a single moment, the constitution of representation merges with the authorisation of the power vested in the authority who is now a representative. She states the following: "A representative is defined as a person who has been given authority to act, and this in turn means a deployment of rights and responsibilities. The representative has been given new rights; the man he represents has taken on new responsibilities, has become responsible for the representative's actions. Applied in the political argument, this notion comes to be a way of establishing the unlimited authority of the sovereign, and his subjects' unlimited obligation to obey" (Pitkin, 1984: 329). 
I will briefly and critically analyse the existing conceptual genealogies of modern political concepts in the Conceptual History (Begriffsgeschichte) tradition. In the next step, I will move to the role played by medieval and Renaissance reinterpretations of Roman philosophy (especially that of Seneca) in the rise of modern concepts (such as sovereignty, people, and representation), which substantially modified classical political language. That would allow a reading of the emergence of modern political concepts that would be different from that of Begriffsgeschichte.

Schmitt (2008) and early Begriffsgeschichte use the idea of a breakaway (Trennung, to use Hegel's term), a rupture regarding the old conception of zoon politikon, to explain the aporetic character of the concept of "liberal democracy", through which "that which is political" takes the form of an apolitical moment whereby - through conceptual technology that allows the use of the right as a dispositif ${ }^{2}-$ struggles and conflicts in the public arena may be neutralised. In these debates and genealogies, we should mention other reconstructions of the emergence of central modern political concepts, such as Michel Foucault's contributions $(2009,2010)$ on how rights were transformed towards the late Middle Ages and Miguel Vatter's work regarding "republics as a kind of state" (2014). Among German authors, Wolfgang Mager $(1968,1984)$ and Hasso Hofmann (2003) are especially noteworthy. I must also mention the historical and conceptual reconstructions of the socalled "republican exclusivism" by James Hankins (2010) and Eric Nelson (2011). I will focus on a specific issue which has not been fully developed by these genealogies, and which owes much to Peter Stacey: ${ }^{3}$ the importance of Seneca as a precedent for political representation, at least in the form that it takes within the representative democratic system.

Stacey (2011a: 9) goes beyond the juxtaposition of Machiavelli (republican) versus Seneca (pro-monarchist), highlighting Seneca's work as a conceptual source of modern absolute sovereignty. De Clementia includes not only a justification for the ruler's absolute power, but also emphasises the need for such a ruler to act as a depersonalised character (ibid.: 22). The Stoic virtues required of Nero make him an impersonal rational ruler free from passions, one who would thus be able to make

2 For a detailed description of concept (dispositif) in Foucault see the chapter "The Confession of the Flesh" in Power Knowledge (Foucault, 1988: 194-195).

${ }^{3}$ Stacey focuses his work on the importance of Seneca's De Clementia as a tool for ideological propaganda promoting princes during the Renaissance. At the same time, it is a central (though not the only) element in Machiavelli's The Prince, which turns out to be its critique and rebuttal. Stacey's work follows in Skinner's footsteps when it comes to reconstructing Machiavelli, but it expands Skinner's genealogy in aspects that seem to have been overlooked or not properly analysed by the British historian. In addition, Tuck (1993: 20) also agrees that the criticism of Seneca is more central than the one of Cicero in Machiavelli's The Prince. 
fair decisions. Impartiality and neutrality were expressions of a sovereign who represented the whole multitude, one shaped thanks to its sovereign. This concept (depersonalization of power) had already appeared in Seneca's works and would later emerge in Bodin's and then in Hobbes'. The first to spot this was Kantorowicz, in his classic book The King's Two Bodies. My hypotheses are as follows: 1. If what Kantorowicz and Stacey have indicated is in fact plausible, then Schmitt's genealogy (2008) and that of early Begriffsgeschichte present the following problem: where they saw a "conceptual revolution" in the form of a modern Trennung, ${ }^{4}$ there was simply an already existing tradition - the Roman one - which had been taken over and reinterpreted. 2. If the concept of "unity" is the key in Seneca's work while "conflict" is central to Machiavelli's, one may ponder on whether liberal democracy might actually be the heir to a tradition which reinterpreted Roman law from a perspective that favoured monarchical forms and was influenced by Seneca, thus developing an idea of representation in line with such a perspective comprising unity among the members of a multitude, contracts, and private property as inalienable rights, the possibility of imposing a state of emergency.

In the following sections, first, I will briefly discuss the Conceptual History, its genealogy, and its critique of modernity. I shall then focus on reclaiming Seneca as a source for modern sovereignty and representation. Finally, I shall close with general remarks on the aforementioned ideas and their weight for both representative democracy and liberalism.

\section{Begriffsgeschichte: A Critique of Modernity}

In Critique and Crisis, Koselleck (1988) $)^{5}$ offers a reconstruction of the process and conditions which fostered the rise of the modern concepts that articulated the Sattelzeit. ${ }^{6}$ Here, one can identify the concept of representation as revolutionary and inseparable from the idea of sovereignty: it is a representative sovereignty. However, to a certain extent, in this reconstruction (strongly influenced by Schmitt), re-

4 According to Bustamante (2015: 5), “interpreting Hegel, Duso pointed out that, in order to understand modern reality, it is necessary to overcome the one-sidedness of the concepts that modern society applies to itself and uses to legitimise the command-obedience relationship, and which have been assumed to be absolute norms". See also Duso, 2004a.

5 Regarding the link that Koselleck established between Hobbes, the Enlightenment and the Liberal tradition, see Chapter II and footnote 39.

${ }^{6}$ In the sense used by Gumbrecht and Koselleck as Zeitbewegung, which expresses a change in consciousness and semantics, not a certain period determined by clearly defined historical events. This change manifests itself in the sciences, arts, politics, literature, etc. It is a change in temporal and linguistic semantics. See Koselleck's "Einleitung" in Geschichtliche Grundbegriffe, Band 1 (Koselleck, Brunner and Conze, 2004). 
presentation is a concept "subordinated" to sovereignty; it is a function carried out by the latter: sovereignty requires representation as its instrument. Its revolutionary nature springs from it having cast aside the classic questions "What is the best form of government?" and "Who should govern?" by radically separating power from a form of government: the former (power) takes precedence over the latter (a form of government). The new key points would be the reasons why it would be reasonable to be subjected to the new power of the State and what mechanism should be applied to lend legitimacy to this power. In this dynamic regarding power arises the need to consider the role of individual rights as limitations to the State power. Thus, in this interpretation, the birth of sovereignty and modern representation is marked by a Trennung with the classical world. ${ }^{7}$ In this narrative, Hobbes is the author who exacted the break. As Italian philosopher Giuseppe Duso (2008) asserted (in line with Otto Brunner, especially), the movement which enables the operation that generates modern sovereignty as representation starts out by eliminating all the differences between the components of a society. Equality among all citizens would be a prerequisite for the geometric construction of politics.

For Hofmann ${ }^{8}$ and Duso, the Hobbesian idea of representation is used to legitimize an absolute power which is at the very heart of modernity. Power does not

7 Regarding Hobbes' role in the transformation of the concepts of justice and law in the Modern legal tradition, see Chignola, 2016.

${ }^{8}$ Hofmann establishes a difference between representation based on a mandate (Vertretung) and representation based on an identity (Repräsentation). This identity representation is typically present in medieval socio-economic order and is structured according to the pars pro toto argument. In this paradigm, a whole, composed by different parts whose political order is prior to the representation of such a whole, is represented through embodiment, which does not require a mandate by consensus or election. Following Grotius, in Hofmann's reconstruction of representation, Hobbes assumes a conception of representative that implies a corporate polity which as a universitas can be represented by the supreme magistrate only (Friedeburg, 2016: 335) and, therefore, departs from the medieval idea of a natural social order reflected in a plurality of corporations that have their own right and autonomy. Combining both identity representation and mandate representation, Hobbes will configure a representative sovereignty reflected in law as command. In Hofmann's reconstruction of Hobbes, there are aspects of a third type: the one related to "making present" (the dialectical relation between Urbild and Abbild). Regarding the reconstruction of Hofmann's argument on Grotius' influence in Hobbes, see Hofmann (2003: 116-285) and Friedeburg (2016: 333-336). For a different perspective, see Zagorin (2000). This argument was first formulated by Hugo Grotius, as Hasso Hofmann has shown. In his De Iure Belli ac Pacis I, chapters III and VII, Grotius, then living in the Paris of Louis XIII, transformed the original argument about the representation of corporations in a radical absolutist way. Until then, it had meant submitting the supreme magistrate, the king, as holder of a mandate from the corporation, similar to a lawyer supervising the property of minors (representatio potestatis), to the corporation as a whole. For that aim, the king had been understood as holding personal sovereignty, whereas the corporation held real sovereignty. The latter could be exercised by an 
mean forcefully limiting an individual's sovereign will, but rather the contrary. According to Duso and Chignola (2008: ch. 4, 5, 8, 10) in this manner, power is legitimised as belonging to everyone and, in consequence, obedience is required from everybody: "obedience here is obedience to leadership emanating from the people who obey themselves".

In this scheme, what becomes relevant is the procedure justifying the sovereign power as absolute power. A multitude of individuals would rationally recognise the need to hand over their sovereignty (in the form of natural freedom) to a sovereign. The separation between power and form of government would mean that the differentiation between political regimes according to the importance given to the notions of justice and prudence becomes totally obsolete. According to the premodern understanding, the function of justice was to establish prudent criteria regarding/for government. This is why the classic idea of politics was articulated around the idea of applying reasonableness when discerning what was fair or unfair. In modernity, the concept of representation gave rise to a procedure whereby power is validated: equal freedom for all is the basis for a system where elections are the mechanism whereby representatives are authorised to act for and before their fellow citizens. This authorisation takes the form of a trust and democracy does not resemble a "government of the people" at all; rather, there is a principal power through which actions are taken in the name of the people albeit without the people. ${ }^{9}$

In that reconstruction, if we take a look at Hobbes and Sieyès, ${ }^{10}$ representing the two foundational moments of modern power, we will find in the former a pro-

assembly being identical with the corporation in question (representatio identitatis). Grotius made no distinction between the body politic and the legal person of the State, the civitas, that subsequently was to be represented by the monarch alone. The German jurist Christoph Besold protested that the head of the body politic must not be confused with the body politic itself. The Grotian and Hobbesian project of introducing their specific notion of the civitas as legal person in order to drop the older notion of an assembly identical with the body politic as a whole was intended effectively to annihilate valid representation of the body politic by anyone but the monarch and to collapse his rule over subjects with the very existence of the body politic. Besold characterized monarchies which failed to respect the difference between monarchical rule and the body politic as "dominatus". The career of the term "despotic" remained connected to an emphasis on proper protection for subjects as citizens with their own household, with whatever procedures and under whatever form of government and that ultimately depended upon enduring republican ideas, if we wish to address the claim for such protection as "republican". Besold, for one, rather participated in a debate about illegitimate tyrants and despots on the one hand and legitimate kings on the other.

${ }^{9}$ Regarding this interpretation and reconstruction of Hobbes, see Duso, 2004b.

${ }^{10}$ Kelly (2004: 127) pointed out: "Murray Forsyth has argued that Hobbes's account of the modern state was, like Sieyes's, based on the 'constituent power of the people' and underpinned by a concept of representation". 
to-theory of constituent power in which it is precisely the people - as an external founding force of political order - who generate a power that then becomes constituted power. That very same constituted power, whose legitimacy derives from the moment originating in constituent power, becomes independent from the people and turns into a discretional power. Sieyès ${ }^{11}$ expressed this same idea derived from Hobbes in his paradox: without a constitution, there is no people and, without a people, there is no constitution. By that same token, the need for such an unstoppable power is driven by the judicial verticalism producing a scenario where there are "equal rights for all", which is described by Sieyès himself as a circle where all parts are equidistant from the centre. ${ }^{12}$

According to Schmitt, Koselleck et al., the idea to criticise modernity starts off by presuming a break - due to conceptual abstractions - from the early modern world through a process of hypostatisation. This hypostatisation of modern concepts means that these act as device categories, that is, as dispositifs: modern concepts generate institutions and individual rights that, on the one hand, result in individual immunity before state power and, on the other, in a depolitisation of civil life. In that sense (concepts as dispositifs), a modern Leviathan would generate security not only through a monopoly on violence, but also through the law, which generates individual immunity.

\section{Problems and Alternative Genealogies}

In the light of Koselleck's Critique and Crisis and Brunner's work, as well as the works of supporters of conceptual history as a criticism of modernity (e.g. Duso, 2004, 2008; Chignola, 1999), I would like to suggest the existence of a genealogical problem. Regarding the emergence of modern concepts as revolutionary devices, first, the contribution of Renaissance authors (such as Machiavelli, Pontano, Guicciardini, Lipsius, etc.) has been undervalued as a bridge between the medieval world and the rise of modernity. Secondly, what has been forgotten is the tradition of Roman philosophy as a key factor in the modification of classical Greek philosophical categories. For example, in both Cicero and Seneca, there are fundamental elements signifying a modification of the idea of virtue and classical prudence. In the Renaissance, Cicero's ideas inform the rise of republicanism more generally and its critique of the notion of virtue in particular (both in its classical and Christian conception). This is relevant for Renaissance criticism of medieval traditions in political philosophy; without this criticism, for example, Machiavelli's new

11 Sieyès' short piece on Hobbes can be found in Pasquale Pasquino (1998: 165-166). On the influence of Hobbes on Sieyès, see Sonenscher, 2003: XLV ff, and Duso, 2004a and 2004b.

12 Regarding this point, see Costa, 2018. 
republicanism or Guicciardini's "ragione degli Stati" would not have been possible.

As I have mentioned before, my hypothesis is that the idea of absolute sovereignty which lies at the very heart of representative democracy has historical-conceptual roots, as Stacey (2011a: 52) has asserted, in a proto-theory of sovereignty and representation contained in Seneca's De Clementia. If this is plausible, the construction of modern sovereignty would not arise from a separation between forms of power and forms of government - as posed by Bodin, for example - nor would it spring from a process of revolutionary conceptual hypostatisation, but rather from identification between power and a particular form of government, a monarchy.

That identification would imply a process of assimilation of the will of the governed to that of the ruler, through which the latter receives sovereignty from the people who recognise his qualities and understand the favourable reasons for subjecting themselves to him. Only then would justice be feasible. In other words, justice can only materialise thanks to the ruler's wisdom. The multitude could never in and of itself generate or guarantee a just order. In Seneca, there are three key steps later taken up by Hobbes (either directly or indirectly through Bodin and Lipsius): ${ }^{13}$

1. The "personification" of the sovereign as a "someone" who appears as a fictional person.

2. The monarch as the provider of political form, which enables a multitude to transform into a people.

3. Seneca's concept of clemency, in which there are elements similar to Hobbes' and Schmitt's decisionism.

There are some common denominators among the different reconstructions of the rise of modern notions of sovereignty and representation. These are the destruction of the medieval order of estates, a concept of "the people" that implies equality among individuals, a process of "security" for "the people" by way of a codification of rights as dispositif, and, lastly, the monopoly on violence kept by the State. ${ }^{14}$

13 According to Hoekstra (2016: 571), "In Lipsius, Hobbes had a shining example of a scholar who had developed a great cultural reputation and significant political influence by providing a great edition of an ancient historian and by offering political lessons for contemporary political and military figures by drawing heavily on Tacitus, Thucydides, and others - all the while hiding behind the figures he is quoting". Regarding the connections between Hobbes and Lipsius, see also Oestreich, 1982: $114 \mathrm{ff}$.

14 Regarding "republican exclusivism", Eric Nelson's interpretation runs parallel to that of J. Hankins. Based on an analysis of the Bible (Deut. 17:14 and 1 Sam. 8), Nelson maintains that there is a controversy about whether God accepted or was angry about the establishment of a human kingdom in Israel. Nelson shows us the possible interpretations striving to harmonise these religious writings and refers to Milton, among others. Pointing to 1 Sam. 8:7, Milton asserts that 
As Hankins (2010) has pointed out, those elements were also present in the transformation which took place during the Renaissance regarding "republican exclusivism", where there was a juxtaposition between republics and principalities (or princedoms). According to Hankins' line of reasoning, Bruni's first work featured a reinterpretation of the Aristotelian distinction between politeia and democracy as that between republic and popularis status. While Bruni sustained the use of republic as a generic form of constitutional structuring, when speaking of the republic of Florence he used the term "republic" in the sense of a sovereign, political association, and applied it to identify non-monarchical political realities. Salutati had politically done this before Bruni. Hankins points out that, in the classical Greek, Roman (where "empire" and respublica were closely related terms), and medieval traditions, there is no juxtaposition between "republics" and "monarchical form". Cicero (1995) had expressed a preference for the former, without denying the legitimacy of the latter. From Cicero's viewpoint, not all monarchies would necessarily be like Tarquins' rule. According to the Roman republican conscience, with the arrival of the Tarquin monarchy, the Roman people lost their freedom because they were now subject to the Tarquins' arbitrary acts. However, this does not negate what Hankins pointed out: that Cicero's work, in itself, recognises that a just monarchy is possible. Among monarchical forms, the rex was associated with the Tarquins while the princeps was not assimilated into the concept of rex. What Cicero indicates regarding republics is that if a State is the organisation of the populus, then a "republic" is "the property of the public, and a public represents a numerous gathering brought together by legal consent and a community of interest" (ibid., 1: 39). It is in the reinterpretation of classical texts during the Renaissance that the idea of understanding the republic as the only form of free State and, therefore, of a legitimate form of government will begin to emerge. In his famous first chapter of The Prince, Machiavelli referred to a distinction which already existed during the Renaissance: there are and have been only two forms of States, republics and principalities, and only

any human kingdom, with a sovereign as its head, means usurping God's kingdom given that no man is fit to be a monarch. By the same token, a monarchy would be an example of the sin of idolatry, leaving republican exclusivism as the only possible form of government compatible with God's instructions. In the case of the German tradition, Mager points out that Kant (in 1795) was the first German philosopher to use the term "republicanism" (Paine's On The Rights of Man was probably the first in the Atlantic tradition to use this concept in 1792; it was translated into German the following year). The suffix "-ism" (in republicanism) is relevant because it designates a gradual, historical, political movement whose implementation - in Kant's case - implies a constitutional principle based on freedom and reason. Both Kant's detractors (e.g. Schlegel) and adherents (Rotteck) linked republicanism exclusively to a form of representative democracy. In the German tradition, linking "republic" to "civil liberty" is not rooted in Kant's writings, but rather in the rehabilitation of the Renaissance notion that republics are non-monarchical forms of government; thus the link between "republic" and "free State" (Freistaat). 
in the first is there freedom. It is in that new version of republicanism that the people must be "ensured against the voraciousness of the aristocracy and the princeps" (Brown, 1988: 86).

In his genealogies of the State and, also, of the concept of republic, Wolfgang Mager identifies a key moment for the emergence of the modern conceptualisation of the State: the reinterpretation of the republic under the idea of status regalis in the Renaissance. This idea derives from Roman private law, not public law, whereby status is bestowed by an individual's dominus as head, whether of a family or even of a city. In consequence, status is something a person possesses. Mager ${ }^{15}$ indicates that, initially, "status" was used as an abbreviation of status regalis, a concept that implied maximum dignity for a king or ruler (whether a duke or something else). In consequence, the meaning of "status" as a concept became gradually dominated by the idea of the highest governing function instead of the idea of a personal characteristic trait. In Mager's reconstruction (Mager, 1968: 455-473), the concept of status expanded before the Reform to include subjects and lordships, in order to explain the implications of a lordship as a function in itself. This would explain in conceptual terms how and why the roots of the modern State are in a monarchical form of government.

According to status regalis, the king becomes head of the entire body politic, representing it in its entirety. This notion would be clear to authors such as Gerson who distinguish the physical, political and spiritual aspects of the king's life. ${ }^{16}$ As Vatter has highlighted, this unity is interpreted as a king who is united with his subjects by law as a head is united to a body in such a way that the interests of that head become identical to those of the body. It is in this unity between the king's civil life and the life of the community that the beginnings of the modern "impersonal" State are founded. Here, the king's laws become the laws that govern the entire body and we see the fundamentally modern idea of the king or sovereign as representative of all the people as the only source of public law.

15 Regarding this point in Mager, see Osiander, 2007: $7 \mathrm{ff}$.

16 According to Mager (1968: 443-444), "Gerson, however, is advised of discretion, which forces him to remain conscious of the unity of king and kingdom. This equation of king and kingdom is similar in the 1413 Oratio. Also, Gerson interchangeably speaks of the civil life of the king or empire and emphasizes the merger of both lives by the caput et membra doctrine. These texts, which were easily reproduced, provide evidence that since the appearance of the caput et membra doctrine, the connection between the syndrome of officium, dignitas, etc., and a ruler, which has been accomplished in the term status regalis, dissolves. In this interrelation, the emphasis on the person becomes ever smaller, until it is finally expelled by the formula of two bodies or the different vitae or esse of the ruler and the status regalis with regnum, universitas, respublica (in a broader sense) identified" (original text in German). 
What Mager saw as a source in private Roman law, Kantorowicz saw in the tradition rooted in Seneca. It is in the context of the Renaissance that Seneca's work was used to defend monarchical forms as the only ones which could guarantee the unity of a multitude by way of justice (Stacey, 2007; Hankins, 2010), compared to the fractionalism that would be proper to the nature of every republic. Furthermore, Seneca's writings appear to have been the source for the reinterpretation of Roman law and a new way of understanding what sovereignty is (Stacey, 2011a; Kantorowicz, 1957).

Looking at these genealogies, it is possible to point out that the starting point for Schmitt, as well as for some of the Begriffsgeschichte initiators, is one-sided reading considering Hobbes as the starting point of the "conceptual modern revolution". Although it is beyond the scope of this article, we could indicate that these genealogical problems also affect Schmitt's political theology, as Victoria Kahn (2014) pointed out.

\section{Reclaiming Seneca}

Kantorowicz (1957) was one of the first twentieth-century authors to point out the importance of Seneca's work De Clementia in the legal transformation which at first enabled the emergence of absolute sovereignty, an idea which was subsequently transformed into the sovereignty of the people. Thus, in Seneca's work, the Roman law idea that "the people's transfer of all imperium and potestas can be reasonably interpreted as a transfer of their sovereignty" takes the form of reconfigured Augustan ideology, bestowing upon the sovereign a supralegal faculty which - in order to be applied and reflect the virtue of clemency, instead of the vice of a whimpering old lady - must involve control of the passions, which was a central part of Stoic morals. The ruler must act as an impersonal judge. This genealogy of sovereignty and representation in the King's Two Bodies differs from that of Koselleck and Schmitt. For example, Kantorowicz even sees the influence of lawyers who reinterpreted Roman law in light of Seneca's monarchical ideas regarding the conditions required for unifying the body politic; however, it is the poiesis of Dante, which would enable a liberal democracy to overcome its origins, changing from the ruler's absolute sovereignty to the sovereignty held by the people.

For Kantorowicz, poiesis is what enables us to ponder human action as not being subject to destiny (whether it be fortune, divine providence, or cosmic forces). That transformation began brewing with Renaissance humanism, but before, during the Middle Ages, there were already the first constitutional exercises which fostered the possibility of looking at power in a secular way. Under the rule of Frederick II, a process was underway in which Seneca's work and his idea of princeps as God's vice-regent played a relevant role in the interpretation of the law. Seneca's work in- 
cludes initial ideas of the monarch viewed from the inside until he appeared in public, in a depersonalised form, as an arbiter deciding over life and death. Thus, sovereignty rested on the monarch's reasonableness due to his vast knowledge of justice and his virtues (see Tuori, 2017: 129). In this manner, reason and representation of sovereignty as an impersonal force would merge into one. Kantorowicz strives to show the historical relevance of this representation for European public law, given that Seneca's ideas based on Augustan ideology were different: they influenced the reshaping of Roman law during the Middle Ages as well as the proto-modern and secular reign of Frederick II.

Kantorowicz views Seneca's work as the basis for the process of State modernisation led by Frederick II, as well as the initial source for Napolitan lawyer Lucas de Penna's interpretation of the body politic and the sovereign. In the first case, Seneca's writings were partly used in order to ideologically justify the emperor's (Frederick II) strengthening of a worldly power independent from that of the Church. ${ }^{17}$ According to Kantorowicz's narrative, this emperor's reign was the first modern European experience regarding the relationship between the State and civil society. In the second case, de Penna used Seneca's ideas as a basis to pinpoint the dual nature of sovereignty: the impersonal sovereign and the person who embodies that sovereignty (see Kantorowicz, 1955: 80).

For his part, and in line with Kantorowicz, Peter Stacey maintains that Seneca's work De Clementia lies at the very foundation of European public law, from the Constitutions of Melfi to Napoleon. While Stacey rejects the idea of a "theory of the state under Frederick II" for being an anachronism, he does agree that, in this ruler's constitutional structuring, there were identifiable elements regarding how to interpret "status" as expressed in Seneca's De Clementia. Such language enabled Frederick II to describe a prince's power as that of an arbiter over life and death who would use his faculty over "fortune, lot, and state".

This allowed Frederick II to annul the difference between rex and princeps, the former being thoroughly disparaged in Roman tradition due to the Tarquin history/ experience. Furthermore, the Holy Roman Emperor was also able to unify under one single person the Papacy's power and the princedoms' monarchical ideology; his power was expressed in the legislative attributions of a rex (see Kantorowicz, 1957: 285). Applying Seneca's theory on the origin of a monarch's powers, the attribute of the Papacy as vicar-mediator between God and earthly powers would have disappeared, since the monarch was now vice-regent. In Seneca, this idea is expressed as a trust, where the trust in a monarch is justified by his ratio. As Kan-

17 According to Stacey (2007: 88), “As Kantorowicz showed, Frederick's sustained self-representation as an absolute monarch embodying iustitia was facilitated by the civilians' rediscovery of a 'non-ecclesiastical Stoicism'". 
torowicz pointed out, such self-representation of an absolute monarch was possible thanks to the legal tradition of that time, which relied on a pagan and secularized form of Stoicism in which reason is able to become one with justice, thus allowing the sovereign to take the form of a veritable deity. In the ideological context described by Stacey, De Clementia stands within the ideology promoted by Res Gestae, in which Augustus is presented as he who will save the republic from chaos and lawlessness. In this sense, it is in the situation prior to the arrival of the princeps, in the figure of Augustus, that the people find themselves subjected to the arbitrary will of unjust individuals. This is why he as a princeps was presented as vindex libertatis. Along these same lines, Seneca confronted the republican tradition which indicated that the sui iuris condition faced risks in monarchical forms because the latter could more easily turn into tyranny, with people being degraded and falling into a state of sub potestatae.

In Roman tradition, the term sui iuris person implied the status of being able to have rights as an individual, but only if one was not subject to the arbitrary will of a third party. Therefore, as Wirszubski noted (1950: 4-5), libertas consisted in being able to possess rights in the absence of subjection as far as civil law was concerned. With regard to libertas of the populi romani, this would involve, first, a notion of sovereignty and autonomy reflected in the concept of "suae leges", which is equivalent to the Greek idea of autonomy. Second, as a corollary of the first idea, there is the exclusion of the monarchical form from materialising politically in a republican regime: it would be a regnum where the people are deprived of their libertas because they are in a state of populus subjectus. It is precisely this aspiration to freedom among the many against the possibility of being oppressed by the few that determined the dynamics of politics in the Roman republic. Cicero was an emblematic figure of this tradition. The sui iuris category is articulated in the distinction between master and slave. The author of De Oficiis and Legibus recognised that tyranny by the few (pauci) over the masses was also possible in the republic. Nevertheless, he sought a compromise (concordia) between the interests of the elite (expressed in the Senate's dignitas) and those of the people (their aspiration to libertas) as a way to reach stability in a political order characterised by a conflict of interests. In this classical Republicanism, its aristocratic nature is reflected in the fact that the ideal of vir bonus is based on the elite's conception of "self-mastery" and reflects the aristocratic nature of the political order.

In order to defend the Republic, in Cicero, magistrates possessed certain virtues which enabled them to act with the common good in mind and not to further private interests. The Ciceronian res publica is an aristocracy which presents itself as representative of the entire body politic. Cicero sought to transform civitas into one single person who, through virtus, could be represented in a unified way through one single mask. 
Along with virtues, the abovementioned required the existence of a proper institutional order by which freedom turns into a status of non-servitude. The mask of virtues and the political-legal structure allowed Cicero to contemplate res publica as res populi.

Conversely, Seneca's ideas were important for the reconfiguring of the Roman monarchist ideology expressed in such texts as Res Gestae Divi Augusti. As Sam Wilkinson has asserted (Wilkinson, 2012: 103-105), the monarchist and ideological character of Seneca's ideas is expressed, among other things, through a language in which rex is already employed to mean "legitimate and just sovereign". In Seneca's linguistic turnabout, we can see the use of paradiastole, by which he sought to place a different value on the semantics of a concept. For the monarchical form he employed representative rhetoric expressions belonging to Roman republicanism, except that now they appear as exclusive properties of the monarch. This also provides the reason why, in De Clementia, the Senate was no longer the representative of the Roman people; it was princeps and rex (which were hard to distinguish from each other). They made it possible for the body politic itself to exist. As Wilkinson (ibid.: 104) pointed out:

... at an earlier day in fact Caesar so clothed himself with the powers of state that neither could be withdrawn without the destruction of both.

And then, he adds:

Seneca presents the princeps as either completely beyond the Law or as the embodiment of the Law. This is in contrast to Livy, for whom Law was the essence of the res publica and protected freedom by constraining all magisterial officers. Where Tacitus presents the Law of the Imperial period as oppressive, a tool of monarchy, Seneca sees it as the right of the monarch, regardless of whether he uses it for good or ill. Seneca does not go as far as Tacitus in suggesting Law is tyrannical. But he assumes that Law is always on the side of the rex, hence his morality becoming crucial. Law is no longer the guardian of freedom.

In Seneca's work, the ideology expressed in Res Gestae Divi Augusti acquires a triple movement of neutralisation of the passions enabling that unified exercise of reason-justice. ${ }^{18}$ First, initial action allows for the possibility of uniting morality (as a reflection of cosmic justice) with human rationality, and through which the "I" would be able to act autonomously. Second, this same autonomy explains the princeps' character as legislator and representative of justice. At another moment, such a monarch would be able to unite poietic creativity with the materialisation

${ }^{18}$ The fact that both texts (De Clementia and Res Gestae Divi Augusti) correspond to the same pro-monarchical ideology does not mean that Seneca himself did not have conflicting ideas regarding Augustus. On that, see Green, 2018. 
of justice in the law. Such a legal justice would reflect natural justice, without one contradicting the other. By the same token, as there is no contradiction between one kind of law and the other, any opposition to political structuring would be incomprehensible and would only reflect inner passions. Third, the creative capacity of the monarch's will - he who embodies justice - implies that, should circumstances require it, he may have to paralyze the law which he himself generated ("a child of his words", as Seneca said) in order to ensure peace. The princeps' virtuous character is what enables the existence of social order, which unifies the people and allows them to prosper in peace. Peace, order, and prosperity are a reflection of the fact that the monarch makes decisions and acts in accordance with justice.

At the end of the day, Seneca's Stoic decisionism is nothing more than the natural consequence of a virtuous triangle made up of inner peace, knowledge of what is just, and the sovereign's will, and it cannot be limited in its capacity to reproduce conditions for peace by any external criteria beyond that of justice united with the sovereign's will. This is why clemency is one of the monarch's mental attributes, an expression of his wisdom applied for the common good. This virtue ratifies the legitimacy of his sovereignty, reflected in the people's love for him and their willingness to ultimately give their lives for him. Clemency demonstrates the monarch's sense of justice, which is not only cognitive: it implies both a mental and a spiritual state, which leads him to be virtuous and allows him to be wise when making decisions for the common good. ${ }^{19}$ This ideological mutation is what drove the emergence of modern sovereignty and gave rise to the idea that it was necessary that a sovereign be the one to foster unity in a multitude within a community of order and peace. This is clearly outlined and expresses Seneca's influence on Bodin (see Bodin, 2009: 218, book 2, chapter 5) and Lipsius (see Stacey, 2015).

In that context, Seneca described Nero as a citizen among citizens precisely to portray him as someone who maintains a tradition, that of the republic as res populi, and is not antagonistic towards citizens, but is rather their defender. Now, regarding Seneca's turnabout in his line of reasoning, the law that matters the most is not the Roman civil code as a work of the people, but the natural law reflected in the ruler's decisions and which every citizen - as a rational agent - must obey and respect.

${ }_{19}$ According to Tuori (2017: 135), "From the passages in De Clementia, it is possible to parse together the image of the emperor as an ideal judge. The duties of the emperor-judge towards the people are threefold. First, he has to be available for the people to approach with their queries. Second, the emperor has to provide security for the people by curtailing offences. Third, the duty of the emperor is to use punishment to guide the behaviour of people, both in individual cases and generally, by setting an example. In all of these actions, the good emperor-judge is led by his clementia, which entails that he would naturally restrict himself from engaging in revenge and cruelty." 
This is why the republic of a prince as described by Seneca does not rest on the law as such, but rather on an idea of rationality which is linked to the Stoic cosmology of universal rationality and cosmic justice. Seneca's monarchical ideology involves a particular interpretation of Stoic morality which links the ruler's rationality to justice and states that the ultimate aim of human life is not the vivere politico, but rather the search for inner peace by cultivating the virtues and learning how to keep passions in check. It is here - when the vivere politico loses its relevance - that Seneca sought to make the absolute sovereignty of the monarch compatible with the freedom of his subjects, a freedom which must be cultivated basically in an individual's inner life and which necessarily requires both justice and peace. They can be guaranteed only by the monarch's power.

In this manner, a person's self is cultivated as long as he voluntarily subjects himself to the dictates of the decreta. ${ }^{20}$ These general norms of morality determine the person's self as a social and moral being. That is the source of the basic precepts which foster and structure human social life. It might be said that all of that is what makes a human being a social being, and that characteristic defines what it is to be a person: the person who participates in social life according to the dictates of the praecepta also acts according to natural law (which conditions the social behaviour of all individuals). It is plausible to assert that a person, as a social agent, is always a fiction of social life who needs to act according to the decreta.

As Schofield (1999) and Stacey (2014) have pointed out, the idea of officium and decorum in the Stoic tradition are common to both Cicero and Seneca. In other words, the possibility of fulfilling the duties of public office implies that proper decorum is needed regarding the moral aspect of an individual's personality. With Cicero, the masks donned by magistrates allowed them to do their job without involving their personal interests; in Seneca's case, it was rationality reflected in the monarch's decisions which enabled him, for example, to act without vengeance.

This allows him to consider the princeps as a vice-regent of the gods who acts among men in their absence. The monarch is the head of the res publica and the people are the body; therefore, this domination over the body is like that of the mind over the human body. This explains why it is not a relationship of servitude and loss of freedom, but rather necessary guidance to prevent the body's death.

${ }^{20}$ According to the traditional interpretation of Stoicism, praecepta are related with moral instructions while decreta are related with moral principles. In Mitsis' interpretation, both correspond to rules (Mitsis, 1993). On the other hand, Inwood suggests that decreta, unlike praecepta, are more theoretical than prescriptive. Decreta, similarly to lex naturae, refer to facts; the difference is that decreta imply a moral sense. Praecepta add injunctions from a moral perspective. As Inwood (2005: 108-155) himself acknowledges, there is some flexibility in Seneca's conceptions of praecepta/decreta/natural law. 
In order to represent and be the head of the body, the first area of domination a ruler must have is that over his own passions. That - imposing the lex naturalis over passions - is what facilitates the unification of both forms of person in one single ruler as a vice-regent of God.

According to Stacey's hypothesis, Seneca's starting point was historical experience, which he used to affirm the need for unity focused on a sovereign; this use of a historical starting point was also the case with Bodin and Hobbes. Fragmentation and conflict were the basic causes of civil war, thus the need to overcome them by absolute sovereignty. In Seneca's writings, there was a pre-designed idea of peace demonstrating why it was convenient to be subjected to a ruler's prudent judgment. If justice existed, it should be reflected in a peaceful coexistence among citizens, and between them and their ruler. In accordance with Stoic tradition, as part of justice and as a relevant element for keeping the peace, Seneca defended the importance of respecting contracts and the limits of private property, as well as the rights which arise from natural, cosmic law. Regarding the influence of both contractualism and cosmic order's natural rights, these elements are also found in Lipsius, Bodin, and Grotius (see Oestreich, 1982).

It is interesting that, according to Foucault, Seneca's importance has to do with the hermeneutics of the self. This French author seeks to determine the conditions for self-control which enable the existence of a power that is no longer an expression of statehood but is, instead, related to relationships of power involving selfreflection. Ethics would be a sort of insight into norms and principles by which the subject limits and governs himself. It is in this context that Foucault analyses the importance of Stoics and Seneca (see Stacey, 2011a: 26). It must be pointed out that Foucault does not consider the effects on civil law, while Seneca touches on moral practices and rules when talking of sovereignty over oneself and then moves on to sovereignty over all.

From a historical viewpoint, upon analysing the mechanisms by which those same processes of self-control among individuals allowed for the modernisation of armies, first, and then of the state bureaucracy, historian Oestreich (1982) concluded that Stoic ethics played a major role by influencing Calvin and then Lipsius. The idea of individual self-regulation (belonging to Stoic ethics) was followed by the idea of necessary discipline in society, which will be reflected in the State (and its bureaucratic model) and its army. Similarly, in Seneca, the sovereign's virtues enable him to neutralise his passions; then it is possible for him to neutralise the power he wields, a condition required if he is to fulfil his duty to unite the people under justice, thereby guaranteeing peace and order. 


\section{General Final Remarks}

To sum up, it is plausible to sustain that the monarchical structure, defended first by Seneca and then by Lipsius and Bodin, is rooted in the traditional Roman idea of concordia as homonoia ${ }^{21}$ and reflected in Hobbes' thinking. The question that arises is whether (as Schmitt and Koselleck pointed out) Hobbes articulates the modern concepts that result in the "conceptual revolution" through which it is possible to articulate liberal representative democracy. If that idea is accepted, there is a problem of neglecting the said influence in Hobbes, which points to an earlier beginning of the genealogy of liberal modernity: Medieval reinterpretations of Seneca's work and Roman law, and their impact in the Renaissance. The multitude that can be represented by a single princeps would have a first source in Seneca's texts.

In Carlo Diano's (1993) already classic separation of form and event, the former seeks to overcome the contingency that is part of life and existence. Contrary to classical thought, the event is a typical feature of modernity in which the possibility of dominating time is a key condition to the feasibility of revolution. That tension between form and event will be at the base of the elective representative democracy: the rule of law will possess sufficient immobility to avoid the permanent contingency of one revolution after another, while, at the same time, including, in itself, the possibility of non-revolutionary change. Seneca's focus is on the form: how to prevent a social order seeking stability from experiencing some kind of destabilising event. Precisely, his transmutation of the sui iuris citizen into that alma iuris (see Schmitt, 1996: 61) (an alma ungoverned by passions, which controls them and is, therefore, autonomous) facilitates the persistence of the idea of freedom as non-servitude, thereby neutralising the uncertainty regarding actions taken by the masses. The sovereign's will, together with justice, is not only the guarantee of stability, but also (as I have already mentioned) of private property and the need to respect contracts. Unlike Schmitt and Koselleck, Foucault understood the need to comprehend the transformation of laws in the medieval world in order to account for the rise of modern ideologies such as the liberal one. However, he did not pay enough attention to the importance of Roman law in that transformation and its subsequent deep impact on the change in political language which took place during the Renaissance. This aspect did not escape Kantorowicz.

If this were correct, the structure of the abovementioned criticism regarding representative democracy and liberalism - starting from Hobbes - would be either

${ }^{21}$ Homonoia refers to an understanding of politics and its structuring as necessarily founded on the agreement that the common good must be reached (when it comes to general interest). It presupposes that a society built on principles and structures recognised by all is more durable and stable. Homonoia is the result of a form (accepted by all) which determines ex ante the possibilities of actions and their subsequent effects. See Raaflaub, Ober and Wallace, 2007. 
incorrect or imprecise. The seventeenth century was a Roman century, with the still highly relevant influence of the Italian Renaissance. Thus, it is in these influences that one must look for the conceptual construct of representative democracy and liberalism if one accepts the idea that, during that century, certain concepts that came to the fore would later converge to become what was to be known as liberalism during the nineteenth century.

\section{Acknowledgements}

I would like to thank Karen Petz for her help with the English language revision of my original article and to my assistant Rodrigo Villalobos. I also want to express my gratitude towards Prof. Luka Ribarević for kindly inviting me to the Summer School of the Faculty of Political Sciences at University of Zagreb (Grožnjan, 2017), where I was able to present my ideas, some of which made it into this work, before an outstanding group of students and professors. This article is part of research project Fondecyt 1170869.

\section{REFERENCES}

Abizadeh, A. 2009. Review: The Radical Hobbes Reviewed Works: The Allegiance of Thomas Hobbes by Jeffrey R. Collins; Subverting the Leviathan: Reading Thomas Hobbes as a Radical Democrat by James Martel. Political Theory, (37) 5: 706-712.

Augustus. 2009. Res Gestae Divi Augusti. Edited by Alison E. Cooley. Cambridge University Press. Cambridge.

Baumgold, D. 1988. Hobbes's Political Theory. Cambridge University Press. New York.

Bodin, J. 2009. On Sovereignty: Six Books of the Commonwealth. CreateSpace Independent Publisher. New York.

Brown, W. 1988. Manhood and Politics: A Feminist Reading in Political Theory. Rowman \& Littlefield. New Jersey.

Brunner, O. 1990. Land und Herrschaft. Grundfragen der territorialen Verfassungsgeschichte Österreichs im Mittelalter. WBG. Wien.

Bustamante, G. 2015. Duso's Critique of Political Philosophy: From Methodology to a Postmodern Retrieval of Democracy. Constellations. An International Journal of Critical and Democratic Theory, (23) 4: 563-572.

Chignola, S. 1999. Begriffsgeschichte in Italy. On the Logic of Modern Political Concepts. Paper presented at the International Forum - Paris, ENS, Saint Cloud EHESS, 14-16 October.

Chignola, S. 2002. History of Political Thought and the History of Political Concepts: Koselleck's Proposal and Italian Research. History of Political Thought, (23) 3: 517-541. 
Chignola, S. 2016. Kelsen, Weber. On Justice and Law, in: Bryan, I., Langford, P. and McGarry, J. (eds): The Foundation of the Juridico-Political. Concept Formation in Hans Kelsen and Max Weber. Routledge. New York.

Cicero. 1995. De re publica. Cambridge Greek and Latin Classics. Cambridge.

Costa, P. 2018. El problema de la representación política: una reconstrucción histórica. Available at: https://www.uam.es/otros/afduam/pdf/8/6900844\%20(015_062).pdf (accessed on 9 May 2018).

Diano, C. 1993. Forma ed Evento. Principi per una interpretazione del mondo greco. Marsilio. Venezia.

Duso, G. 2004a. Génesis y lógica de la representación política moderna. Fundamentos, 3: 56-57.

Duso, G. 2004b. Hobbes et l'invention moderne du pouvoir. Hobbes Studies, (17) 1: 28-45.

Duso, G. 2008. Il potere e la nascita dei concetti politici moderni, in: Duso, G. and Chignola, S. (eds): Storia dei concetti e filosofia politica. Ed. Franco Angeli. Milan: 161-172.

Duso, G., Chignola, S. 2008. Storia dei concetti e filosofia política. Ed. Franco Angeli. Milan.

Foucault, M. 1988. Power Knowledge. Random House USA. New York.

Foucault, M. 2009. Security, Territory, Population: Lectures at the Collège De France 1977-1978. Picador. New York.

Foucault, M. 2010. Birth of Biopolitics: Lectures at the Collège de France, 1978-1979. Picador. New York.

Friedeburg, R. 2016. Luther's Legacy: The Thirty Years War and the Modern Notion of 'State' in the Empire, 1530s to 1790s. Cambridge University Press. Cambridge.

Galli, C. 2010. Genealogia della politica: Carl Schmitt e la crisi del pensiero politico moderno ( $2^{\text {nd }}$ ed.). Il Mulino. Bologna.

Green, S. J. 2018. Seneca's Augustus: (Re)calibrating the Imperial Model for a Young Prince, in: Penelope J. Goodman (ed.): Afterlives of Augustus, AD 14-2014. Cambridge University Press. Cambridge: 44-57.

Hankins, J. 2010. Exclusivist Republicanism and the Non-Monarchical Republic. Political Theory, (38) 4: 452-439.

Hofmann, H. 2003. Repräsentation. Studien zur Wort- und Begriffsgeschichte von der Antike bis ins 19. Jahrhundert. Duncker \& Humblot. Berlin.

Hofmann, H. 2013. Le concept de représentation: un problème allemand? Raisons politiques, 50: 79-96.

Hobbes, T. 1983. De Cive. Edited by Howard Warrender. Oxford University Press. Oxford. Hobbes, T. 2014. Leviathan. Edited by Noel Malcolm. Oxford University Press. Oxford. Hoekstra, K. 2016. Hobbes's Thucydides, in: Martinich, A. and Hoekstra K. (eds): The Oxford Handbook of Hobbes. Oxford University Press. Oxford: 547-574. 
Inwood, B. 2005. Reading Seneca. Stoic Philosophy at Rome. Oxford University Press. Clarendon.

Kahn, V. 2014. The future of Illusion. Political Theology and Early Modern Texts. University of Chicago Press. Chicago.

Kantorowicz, E. 1955. Mysteries of State: An Absolutist Concept and Its Late Mediaeval Origins. The Harvard Theological Review, (48) 1: 65-91.

Kantorowicz, E. 1957. The King's Two Bodies. A Study in Medieval Political Theology. Princeton University Press. Princeton.

Kelly, D. 2004. Carl Schmitt's Political Theory of Representation. Journal of the History of Ideas, (65) 1: 113-134.

Koselleck, R. 1988. Critique and Crisis. MIT Press. Cambridge.

Koselleck, R. 2004. Futures Past: On the Semantics of Historical Time. Columbia University Press. New York.

Koselleck, R. 2006. Begriffsgeschichten. Suhrkamp Verlag. Frankfurt.

Koselleck, R. 2011. Introduction and Prefaces to the Geschichtliche Grundbegriffe (trans. M. Richter). Contributions to the History of Concepts, (6) 1: 1-37.

Koselleck, R., Brunner, O. and Conze, W. 2004. Geschichtliche Grundbegriffe. Historisches Lexikon zur politisch-sozialen Sprache in Deutschland, Band 1. Klett-Cotta Verlag. Stuttgart.

Lehmann, H., Richter, M. (eds). 1996. The Meaning of Historical Terms and Concepts. New Studies on Begriffsgeschichte. German Historical Institute, Occasional Paper $\mathrm{N}^{\mathrm{o}} 15$.

Lehmann, H., Van Horn Melton, J. 1994. Paths of Continuity: Central European Historiography from the 1930s to the 1950s. Cambridge University Press. Cambridge.

Lipsius, J. 2006. Politica: Six Books of Politics or Political Instruction. Edited by Jan Waszink. Leuven University Press. Leuven.

Machiavelli, N. 1988. The Prince. Edited by Quentin Skinner and Russell Price. Cambridge University Press. Cambridge.

Mager, W. 1968. Zur Entstehung des modernen Staatsbegriffs. Abhandlungen der Geistes- und Sozialwissenschaftlichen Klasse / Akademie der Wissenschaften und der Literatur, no. 9. Verl. der Akad. der Wiss. und der Literatur [u.a.]. Mainz.

Mager, W. 1984. Republik, in: Koselleck, R., Brunner, O. and Conze, W. (eds): Geschichtliche Grundbegriffe. Historisches Lexikon zur politisch-sozialen Sprache in Deutschland, vol. 5. Klett-Cotta Verlag. Stuttgart: 549-651.

Martinich, A. P., Hoekstra, K. 2016. The Oxford Handbook of Hobbes. Oxford University Press. Oxford.

Mitsis, P. 1993. Seneca on reason, rules, and moral development, in: Brunschwig, J. and Nussbaum, M. (eds): Passions and Perceptions: Studies in Hellenistic Philosophy of Mind. Cambridge University Press. Cambridge: 285-312. 
Nelson, E. 2011. The Hebrew Republic. Harvard University Press. Cambridge.

Oestreich, G. 1982. Neostoicism \& The Early Modern State. Cambridge University Press. Cambridge.

Osiander, A. 2007. Before the State: Systemic Political Change in the West from the Greeks to the French Revolution. Oxford University Press. Oxford.

Pasquino, P. 1998. Sieyès et l'invention de la constitution en France. Editions Odile Jacob. Paris.

Pitkin, H. 1984. The Concept of Representation. University of California Press. California.

Raaflaub, K., Ober, J., Wallace, R. (eds). 2007. Origins of Democracy in Ancient Greece. University of California Press. Berkeley, California.

Runciman, D. 2010. Hobbes's theory of representation: anti-democratic or proto-democratic?, in: Shapiro, I., Stokes, S. and Wood, E. J. (eds): Political Representation. Cambridge University Press. Cambridge.

Seneca. 2010. Anger, Mercy, Revenge. (Translated by Robert A. Kaster and Martha C. Nussbaum). Chicago University Press. Chicago.

Schelsky, H. 1981. Thomas Hobbes. Eine politische Lehre. Duncker \& Humblot. Berlin.

Schmitt, C. 1996 [1938]. The Leviathan in the State Theory of Thomas Hobbes: Meaning and Failure of a Political Symbol (introd. Schwab, G., trans. Schwab, G. \& Hilfstein, E.). University of Chicago Press. Chicago.

Schmitt, C. 2008. The Concept of the Political (Expanded Edition). University of Chicago Press. Chicago and London.

Schofield, M. 1999. The Stoic Idea of the City. University of Chicago Press. Chicago.

Sieyès, E. 2003. Political Writings. Hackett Publishing. Indianapolis.

Skinner, Q. 1991. Two Views on the Maintenance of Liberty, in: Pettit, P. (ed.): Contemporary Political Theory. McMillan. New York: 35-58.

Skinner, Q. 1998. Liberty before Liberalism. Cambridge University Press. Cambridge.

Skinner, Q. 2002. Visions of Politics. vol. 2 and vol. 3. Cambridge University Press. Cambridge.

Skinner, Q. 2008. Hobbes and Republican Liberty. Cambridge University Press. Cambridge.

Sonenscher, M. 2003. Introduction, in: Sieyès, E., Political Writings: Including the Debate Between Sieyès and Tom Paine in 1791. Edited by Michael Sonenscher. Hackett Publishing Company. Indianapolis: vii-lxiv.

Stacey, P. 2007. Roman Monarchy and the Renaissance Prince. Cambridge University Press. New York.

Stacey, P. 2011a. The Sovereign Person in Senecan Political Theory. Republics of Letters: A Journal for the Study of Knowledge, Politics, and the Arts, (2), 2. Available at: https://arcade.stanford.edu/rofl/sovereign-person-senecan-political-theory. 
Stacey, P. 2011b. Free and Unfree States in Machiavelli's Political Thought, in: van Gelderen, M. and Skinner, Q. (eds): Freedom and the Construction of Europe. Cambridge University Press. Cambridge.

Stacey, P. 2012. Justus Lipsius and the Post-Machiavellian Prince, in: Brooke, C. (ed.): Philosophic Pride: Stoicism and Political Thought from Lipsius to Rousseau. Princeton University Press. Princeton.

Stacey, P. 2014. The Princely Republic. Journal of Roman Studies, 104: 133-154.

Tuck, R. 1993. Philosophy and Government 1572-1651. Cambridge University Press. Cambridge.

Tuck, R. 2006. Hobbes and Democracy, in: Brett, A., Tully, J. and Hamilton-Bleakley, H. (eds): Rethinking The Foundations of Modern Political Thought. Cambridge University Press. Cambridge: 171-190.

Tuori, K. 2017. The Emperor of Law. The Emergence of Roman Imperial Adjudication. Oxford University Press. Oxford and New York.

Vatter, M. 2010. Republicanism or Modern Natural Right? The Question of the Origins of Modern Representative Democracy and the Political Thought of Giuseppe Duso. CR: The New Centennial Review, (10) 2: 99-120.

Vatter, M. 2014. Republics are a Species of State: Machiavelli and the Genealogy of the Modern State. Social Research: An International Quarterly, (81) 1:217-241.

Vatter, M. 2019. Liberal Governmentality and the Political Theology of Constitutionalism, in: Walker, N. and Leijssenaar, B. (eds): Sovereignty in Action. Cambridge University Press. Cambridge. Forthcoming.

Wallace-Hadrill, A. 1981. The Emperor and His Virtues. Historia: Zeitschrift für Alte Geschichte, (30) 3: 298-323.

Wallace-Hadrill, A. 1982. Civilis Princeps: Between Citizen and King. The Journal of Roman Studies, (72): 32-48.

Wilkinson, S. 2012. Republicanism during the Early Roman Empire. Bloomsbury. London.

Wirszubski, C. 1950. Libertas as a Political Idea at Rome During the Late Republic and Early Principate. Cambridge University Press. Cambridge.

Zagorin, P. 2000. Hobbes without Grotius. History of Political Thought, (21) 1: 16-40.

Mailing Address: Gonzalo Bustamante Kuschel, Professor of Political Philosophy, School of Government, Universidad Adolfo Ibáñez, Diagonal las Torres 2640 Peñalolén, Santiago, Chile.E-mail: gonzalo.bustamante@uai.cl 